\title{
SOME ISSUES IN PLANNING AND REVITALIZATION OF URBAN GREEN SPACE IN THE LIGHT OF USE OF THE PARTICIPATORY GIS METHOD BASED ON OLSZTYN GEOSURVEY - STUDY RESULTS (part 2) ${ }^{1}$
}

\author{
${ }^{1}$ Department of Geomatics and Cartography, Faculty of Earth Sciences, Nicolaus Copernicus University, \\ Lwowska Str.1,87-100 Torun, kamila.walenciak@o2.pl, korzen@umk.pl \\ ${ }^{2}$ Department of Landscape Architecture, Faculty of Environmental Management and Agriculture, \\ University of Warmia and Mazury in Olsztyn, Prawocheńskiego Str. 17, 10-727 Olsztyn, \\ mariusz.antolak@uwm.edu.pl
}

Keywords: softGIS, geosurvey, volunteered geographic information (VGI), participatory GIS, public participation, landscape architecture, spatial planning, PostGIS, Django, webGIS, social shaping of urban space

\begin{abstract}
An Internet application in the form of geosurvey was designed and created for the aim of the study. An online survey, entitled promotionally "Have Influence on Olsztyn Green Space!" was on from mid-October 2014 to the end of January 2015. Respondents (residents of Olsztyn and the surrounding area) expressed their opinions and assessments on green spaces and recreation areas in the city on the geoankietaolsztyn.pl website. Based on voluntary geographic information, spatial analyses of urban greenery perception were made at the level of three scales: the town, the housing estate, the nearest area.

The paper presents a diagramme of the study process related to the problem of designing and revitalizing Olsztyn urban green space with the use of the participative GIS method (softGIS).

The suggested stages of the study process are:

1) Identification of respondents general opinion on and assessment of green areas

2) Social development of urban space based on the perception of the area of residence

3) Analysis of detailed spatial data - respondents' suggestions for changes

4) Identification and development of positive, friendly and important places in the city or housing estate

5) Attempt to formulate design guidelines.

Selected results of the study have been presented in various parts of the paper.

The results of the first stage serve to focus the general attention on areas of action that, according to residents, are not functioning well enough and need improvement.

\footnotetext{
1 The paper was developed in two parts, based on a research conducted as a master's degree thesis entitled „Wybrane problemy niu (Department of Geomatics and Cartography, Faculty of Earth Sciences, Nicolaus Copernicus University, under the guidance of, Dr hab. Zenon Koziet, NCU Professor. In its first part entitled Założenia metodyczno-technologiczne zastosowania GIS'u partycypaparticipatory GIS method in planning and revitalization of urban green space (part 1)) the issue of public space shaping was presented
} projektowania i rewitalizacji terenów zieleni miejskiej Olsztyna w świetle zastosowań innowacyjnych metod GIS'u partycypacyjnego" (Some issues in planning and revitalization of urban green space in the light of use of the participatory GIS method based on Olsztyn geosurvey) in the Katedra Geomatyki i Kartografii na Wydziale Nauk o Ziemi Uniwersytetu Mikołaja Kopernika w Torucyjnego do projektowania i rewitalizacji terenów zieleni miejskiej (cz. 1) (Methodical and technological assumptions for using of the - the softGIS method applied in the research was characterised as the background of the project, and the technological aspect of the project - the structure of the geosurvey and the Internet application were discussed..
\end{abstract}


Step two shows an average assessment of space in terms of a given factor to determine its social reception. Its effect is the development of the space under study, which is to reflect the degree of its social acceptance. Stage three is the main and most important stage in the study process. Its implementation may complement the two previous ones, and serves to draw up the guidelines for the design and revitalization actions, and to diagnose the most difficult areas in the scale of the city, or it can be carried out independently so as to follow the diagnosed local needs of the population. The social assessment of the sites in terms of the adopted factors in the fourth stage at the background of the expert opinion, may be successfully used to draw up urban greenfield programmes. The most valuable sites require different guidelines for their maintenance and use in order to protect them. The summary of the study process was an attempt to form general design guidelines (assumptions) for the whole city in line with detailed guidelines for selected urban green spaces, in form of land cards as master cards.

\title{
WYBRANE PROBLEMY PROJEKTOWANIA I REWITALIZACJI TERENÓW ZIELENI MIEJSKIEJ W ŚWIETLE ZASTOSOWAŃ INNOWACYJNYCH METOD GIS'U PARTYCYPACYJNEGO NA PRZYKLADZIE OLSZTYŃSKIEJ GEOANKIETY - WYNIKI BADAŃ (cz. 2)²
}

Słowa kluczowe: softGIS, geoankieta, wolontariacka informacja geograficzna, GIS partycypacyjny, partycypacja społeczna, architektura krajobrazu, planowanie przestrzenne, PostGIS, Django, webGIS, społeczne kształtowanie przestrzeni

\begin{abstract}
Abstrakt
Na potrzeby badania została zaprojektowana i utworzona aplikacja internetowa w postaci geoankiety. Badanie internetowe, pod hasłem promocyjnym „Wpłyń na zielony Olsztyn!”, przeprowadzono od połowy października 2014 r. do końca stycznia 2015 r. Na stronie geoankietaolsztyn.pl respondenci (mieszkańcy Olsztyna i okolic) wyrażali swoje opnie i oceny odnośnie do zielonej przestrzeni i miejsc rekreacji w mieście. Na podstawie wolontariackiej informacji geograficznej zostały dokonane analizy przestrzenne percepcji zieleni miejskiej na poziomie trzech skali: miasto, osiedle, najbliższa okolica.

Artykuł prezentuje schemat procesu badawczego dotyczącego problematyki projektowania i rewitalizacji zielonej przestrzeni miejskiej Olsztyna przy zastosowaniu metody GIS'u partycypacyjnego (softGIS).

Zaproponowane etapy postępowania badawczego to:

1) Rozpoznanie ogólnej opinii i oceny respondentów względem terenów zieleni.

2) Społeczna waloryzacja przestrzeni miejskiej na podstawie percepcji okolicy miejsca zamieszkania.

3) Analiza szczegółowych danych przestrzennych - wskazań respondentów w zakresie propozycji zmian.

4) Identyfikacja i waloryzacja miejsc pozytywnych, przyjaznych i ważnych w skali miasta lub osiedla.

5) Próba sformułowania wytycznych projektowych.
\end{abstract}

W poszczególnych częściach artykułu zostały przedstawione wybrane wyniki badań.

Wyniki etapu pierwszego służą zwróceniu ogólnej uwagi na obszary działania, które według mieszkańców nie funkcjonują wystarczająco dobrze i wymagają udoskonalenia.

Etap drugi ukazuje uśrednioną ocenę przestrzeni pod względem danego czynnika determinującego jej społeczny odbiór. Jego efektem jest waloryzacja badanej przestrzeni, będąca obrazem stopnia jej akceptacji społecznej. Etap trzeci to główny i najważniejszy etap w procesie postępowania badawczego. Jego realizacja może stanowić uzupełnienie dwóch poprzednich etapów, służąc do opracowania kierunków działań projektowych i rewitalizacyjnych oraz diagnozowania obszarów najbardziej problemowych w skali miasta, bądź też może być prowadzona niezależnie, w ramach diagnozy lokalnych potrzeb mieszkańców. Społeczna ocena obiektów pod względem przyjętych czynników w etapie czwartym, w zestawieniu z oceną ekspercką, może być z powodzeniem wykorzystywana podczas sporządzania programów kształtowania terenów zieleni miejskiej. Obiekty naj-

\footnotetext{
${ }^{2}$ Artykuł został opracowany w dwóch częściach, na podstawie badania przeprowadzonego w ramach realizacji pracy magisterskiej pt. „Wybrane problemy projektowania i rewitalizacji terenów zieleni miejskiej Olsztyna w świetle zastosowań innowacyjnych metod GIS'u partycypacyjnego", w Katedrze Geomatyki i Kartografii na Wydziale Nauk o Ziemi Uniwersytetu Mikołaja Kopernika w Toruniu, pod kierunkiem dr hab. Zenona Kozieła, prof. UMK. W pierwszej części pt. Założenia metodyczno-technologiczne zastosowania GIS'u partycypacyjnego do projektowania i rewitalizacji terenów zieleni miejskiej (cz. 1) przedstawiono problematykę społecznego kształtowania przestrzeni - jako tło projektu, scharakteryzowano zastosowaną w badaniu metodę softGIS oraz omówiono konstrukcję kwestionariusza geoankiety i aplikacji internetowej - jako technologiczny aspekt projektu.
} 
bardziej wartościowe wymagają odmiennych wytycznych dotyczących ich utrzymania i użytkowania w celu ich ochrony. Podsumowaniem procesu badawczego była próba sformułowania wytycznych projektowych (założeń) ogólnych w skali całego miasta oraz wytycznych szczegółowych dla wybranych obiektów zieleni miejskiej, w postaci tzw. kart terenów, jako kart wzorcowych.

\section{INTRODUCTION}

An Internet application in the form of geosurvey was designed and created for the aim of study. An online survey, entitled promotionally "Have Influence on Olsztyn Green Space!" was on from mid-October 2014 to the end of January 2015. Respondents (residents of Olsztyn and the surrounding area) expressed their opinions and assessments on green space and recreation areas in the city on the geoankietaolsztyn.pl website.

254 people participated in the study, which means that 254 geosurveys were filled. Owing to the fact that the respondents had the opportunity to supplement only selected issues (some cards), most geosurveys were incomplete. Full geosurveys were considered those whose all pages from 1 to 6 were filled in (card 7 is an additional element that allows respondents to add their own notes). In consequence, the database contains 63 full geosurveys.

Most selections related to the leisure-time places (561 of them). The comparable number of selections referred to places with no greenery (237) and to important and valuable ones (202). The fewest places marked were those of residence. Only 101 of the 254 respondents rated the area of their residence.

The acquired data are of substance which is proven by the attached extended comments and notes. In general, the study raised much interest, but also involved the residents. The database was enriched by an average of more than 9 selections per day. The analysis of the sites indicated by respondents, as well as of all the comments, allows to claim that in most cases, the decisions on the choice of places were not incidental, and in addition, they were thoroughly thought out and supported by statements of reasons.

Based on the information obtained with the help of the designed geosurvey, multi-faceted research and analyses were possible. Within the implementation of the project objectives, selected issues were identified and a clear research plan for the use of voluntary information on the space was suggested in the design and revitalization of urban green spaces.

Selected study results of each stage are discussed later in this paper.

\section{RECOGNITION OF GENERAL OPINION AND RESPONDENTS' RATING OF GREEN AREAS}

This stage shows the opinions of space users on the development of individual green areas in the city, as well as, suggestions how to change urban greenery direction of development, shaping and management. It serves to draw attention to areas of activity that residents criticize as not functioning well enough and in need to be improved. It is effected based on answers from card 6 ("Additional Information") and 7 ("End"). These are qualitative non-spatial data, also obtainable with the use of traditional surveys, as well as, cyclical public opinion surveys.

Most respondents pointed to pedestrian and cycling paths ( $74.1 \%$ of people) in need of improvement and the care of greenery $(70.4 \%)$ to be worked on. A little more than $60 \%$ of respondents are of the opinion that greater care shall be taken to equip green areas. More than 57\% of respondents were for an enlargement of green areas, and no one indicated the answer, suggesting to reduce the area. Fewer than half of respondents voted for an increased diversity of plants and plant compositions, better accessibility of green spaces for the disabled and baby prams and for new amenities. In addition, 37\% of respondents believe that more seasonal green areas shall be introduced in Olsztyn and $30 \%$ of them are aware of lacking security.

The overall assessment of green areas was important for the pre-assessment of the individual city's green spaces. Five types of green areas were rated: parks, squares/greens, HE greenery, recreation and sport grounds/playgrounds along with street greenery with the help of five-level scale (with the "I have no opinion" option included). More than one half of 108 people to rate green areas were of the opinion that parks are of unremarkable development. Only $2 \%$ of respondents consider them very bad, and as many people consider them very good. It is worth underlining that as many as $37 \%$ of the responses included high rating, which means the greatest satisfaction of the residents with park development, of all types of green areas in the city. This is certainly due to the revitalization and increased 
value of park areas (e.g Centralny Park/Central Park and Park Podzamcze/Castle Park) undertaken in recent years, which has increased the number of their users. The second best type of green areas that received positive ratings (18\% high and $3 \%$ very high) are recreation and sports grounds and playgrounds. The favourable adaptation to the recreation purposes of the wharf of Długie Lake and the investment on Lake Ukiel contribute to better satisfaction of the residents with their development. Squares, greens and yards received only $2 \%$ of high scores and $6 \%$ of very high ones. $43 \%$ of those under survey rate their development as unremarkable, $35 \%$ as low and $11 \%$ as very low. Housing Estates' greenery has got a worse score. As many as $29 \%$ of responses indicate the lowest score. A similar response related to the street greenery.

\section{PUBLIC INCREASING OF VALUE OF MUNICIPAL SPACE BASED ON THE PERCEPTION OF RESIDENTS' NEIGHBOURHOOD}

The other suggested stage of research work with reference to design needs and revitalization of municipal space consists in its development, based on public perception of the residents' neighbourhood. This stage shows an averaged assessment of the space with regard to a given (adopted) factor which is determinant for the public reception. Then, it presents a summary assessment of the space, taking into account all (or selected, depending on the purpose of research) averaged assessments of individual factors. Its effect is the development of the space under study, making up the degree of its public acceptance.

In the research, to assess the quality of Olsztyn municipal space, the responses of respondents from card 5 of the geosurvey were used. They related to the residence neighbourhood. The residents were requested to assess their residence neighbourhood with regard to various five neighbourhood factors (research factors). The analysis of professional literature had an influence on the choice of factors under survey in line with the adjustment of quality ratios of municipal space to the purpose of research. As the survey was to serve to designing, revitalizing and managing the green space and to facilitate the increase in the public importance of green areas, the following factors were assumed to be rated: the quantity of green places, its quality, poten- tial to spend leisure time there (amenities to promote resting and recreation), safety, special governance (nice appearance).

Each factor was assessed on a five-grade scale. In answer to the question: "How do you assess the nearest neighbourhood of your residence?" (with regard to the individual factors), the following replies could be chosen: very bad, bad, moderate, high, very high. For the needs of analyses, quality attributes were given numerical values, correspondingly $-2,2,0,1$, and 2 , where -2 means the worst score and 2 the best one. In the case the respondent was not able to express their opinion, they would use "I have no opinion" answer. Such situations were rare and they had no impact on the final assessment. Sites which were not rated with regard to a given factor were discarded from the further research proceedings. That explains why the range of area subject to assessment in individual partial increase of value is not identical.

For the needs of area development, the method of arithmetical mean was applied (X) of partial ratings (individual observations $-\mathrm{x}$ ) of residence neighbourhood (or else in the graphic presentation - circles overlaying). The arithmetical mean of assessments is calculated for each raster cell in the range of the given circles. In the case, a given space has been rated by one person, the arithmetical mean is equivalent to the individual assessment (figure 1). Numerical values were attributed to circles (buffers of a radius of $500 \mathrm{~m}$ from the places of residence) from -2 to 2 i.e. grades awarded in the survey, separate for each factor.

The radius of residence neighbourhood rating has already been suggested in the questionnaire. Its value mainly results from the area and scale of the study. The analysis is done for the whole city, and therefore, it involves identifying of problem areas in the scale of the city. Were the city to identify problem areas such as within a given housing estate, the radius could be $200 \mathrm{~m}$.

The detail level of results is determined by the size of the raster cell. The larger the size of a cell, the smaller the detail is, but the visualization of data becomes smoother. The selection of the cell size depends on the scale the results are presented in (K. Hasanzadeh 2014). The size of the cell adopted for this study as $100 \mathrm{~m}$, compared with other sizes (50 and $250 \mathrm{~m}$ ), was considered representative for the best degree of detail in relation to the scale of the study. 


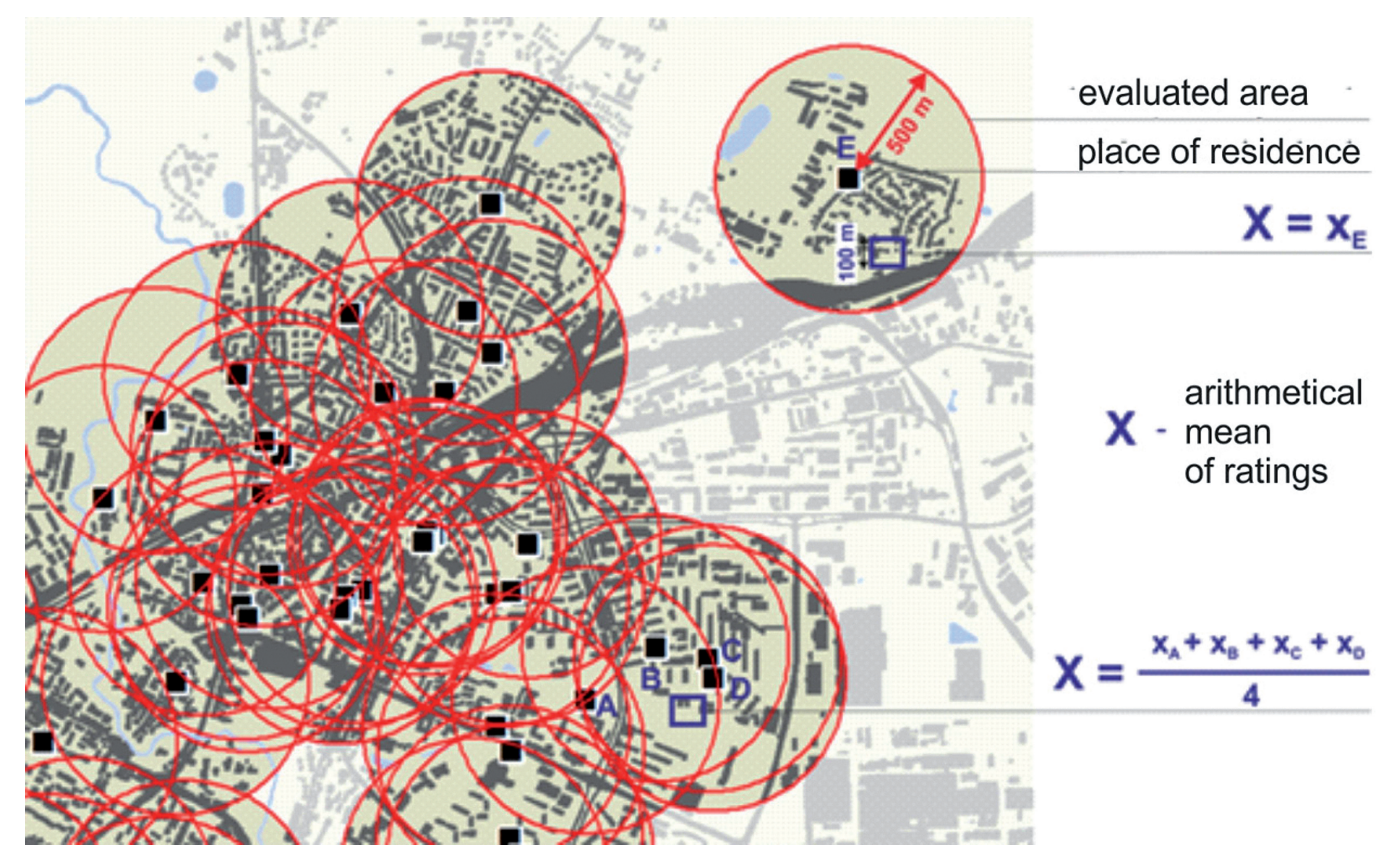

Fig. 1. Explanation of the method of arithmetical mean of partial assessments for the needs of increase in value of space Rys. 1. Objaśnienie zastosowanej metody średniej arytmetycznej ocen cząstkowych na potrzeby waloryzacji przestrzeni

Since the perception of space has fluid and transitory nature (it is not possible to set a clear boundary between specific perceptions), the results have been interpolated and presented on a continuous scale.

101 people evaluated the neighbourhood of their place of residence, out of 254 of those who took part in the research. Therefore, the scope of space assessment is limited and does not cover all residential areas in the city. However, the assumption for the method applied to evaluate the space is to achieve as many observations as possible in each housing estate. In this case, the expression used by M. Skiba (2008) proves to be true: "The method to make more objective the subjective ratings is to increase the number of evaluating persons. This objectification is based on the guideline that the average value of many independent ratings is closer to the objective evaluation." Therefore, the more observations are included in the study to characterize the whole study area, the more valuable the results are and the more representative they become. Due to the fact that in online studies of this type, the share of residents is voluntary, the number and distribution of observations are random. However, in the course of further study, a controlled sample selection may be considered.

\section{RATING}

Figure 2 shows one of partial maps, i.e., the development of the quality of space in terms of one of the five factors proposed to study (diagnostic traits) - the quantity of greenery. From the point of view of greenery quantity, the urban space of the following enjoys the least public acceptance: in the southern part of the Generałów Housing Estate, in the south-west part of the Jaroty estate, in the city centre, in the western part of Kętrzyński and Pojezierze Housing Estates, in the south-eastern part of the Kościuszki Housing Estate, in the northern part of the Nagórki Housing Estate. The remaining areas, evaluated as to their greenery, received an average or a positive rating (high and very high).

Having summed up all the values from all the partial maps, the resulting map was obtained with the general public development of the space. The average values for each of the five factors were added altogether, so as a result, in the overall assessment, the highly rated area received the value of 10 and the very low rating was -9.5 (none of the neighbourhood of residence places were awarded the five lowest ratings).

In the overall assessment of the space quality (taking into account all analyzed factors), most areas within 


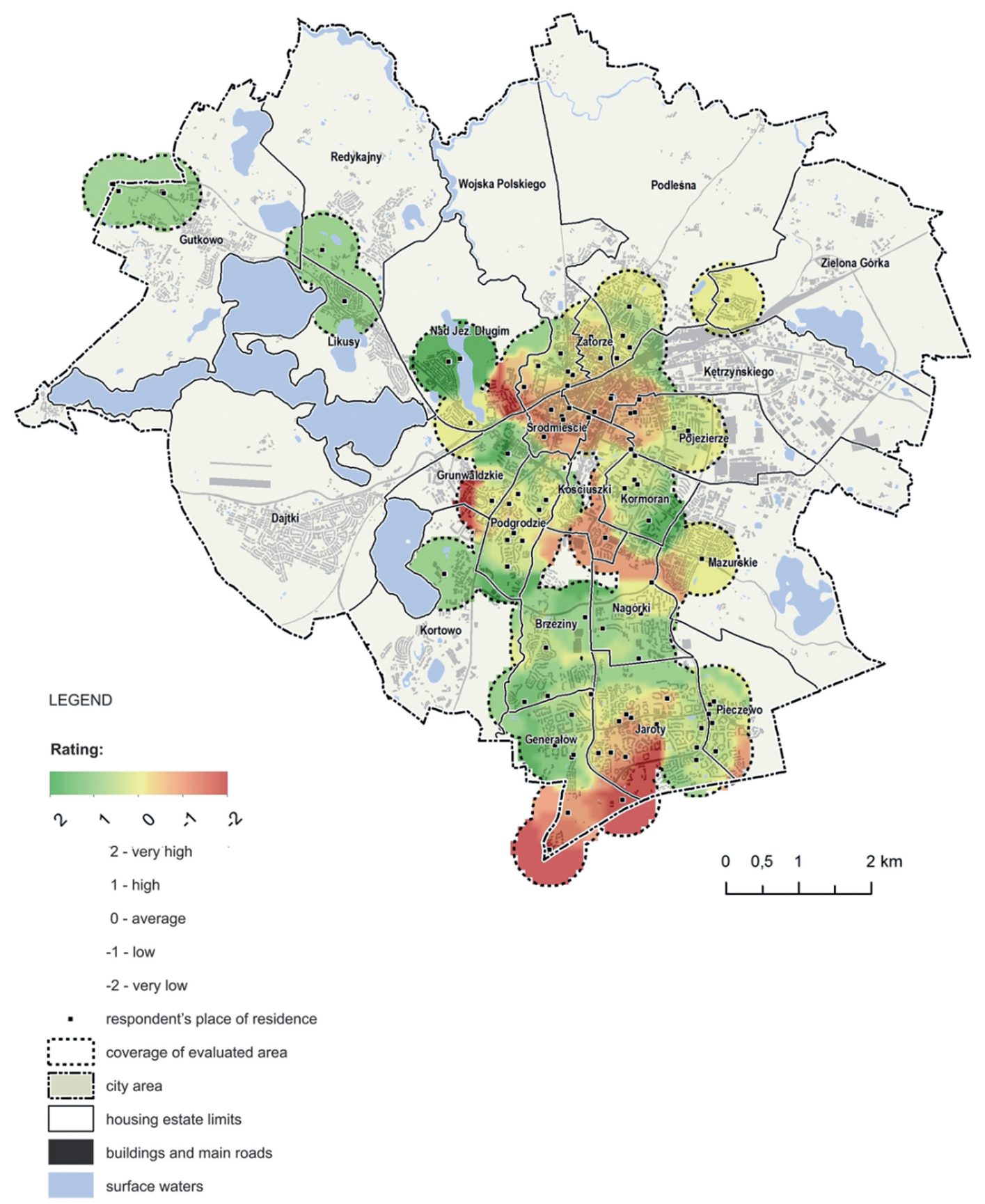

Fig. 2. Public space value adjustment based on average ratings of places of residence (assessed factor: quantity of greenery) Rys. 2. Społeczna waloryzacja przestrzeni na podstawie średniej ocen okolic miejsc zamieszkania (czynnik oceniany: ilość zieleni)

the development range prove to be average or below average. The areas least valued by the inhabitants are: south-western part of the Jaroty Housing Estate, south part of the Generałów Housing Estate, city centre, western part of Kętrzyński and Pojezierze Housing Estate, north and south part of Kościuszki Housing Estate.
The space in the vicinity of Lake Długie features the highest quality, according to respondents, along with the western part of Gutkowo Housing Estate. However, it shall be emphasized that the final average rating is closest to the objective one in the case of very large number of observations, in the survey in question, i.e. in 
the city centre and in Jaroty, Pieczewo and Generałów HEs. Single observations in peripheral housing estates do not provide results of value. To gain more opinions from more numerous residents would be necessary in future studies on the space quality in the whole city. In order to have more detailed results, with a larger number of observations, it is worth considering a reduction in the radius of the environment, e.g. to $200-250 \mathrm{~m}$. Then, the results will be more differentiated.

The implementation of the discussed stage of study, i.e. drawing up public development with regard to urban space aims at becoming familiar with the public acceptance of space in terms of various factors, influencing its quality and attractiveness. This facilitates a pre-diagnosis of problem areas in specific fields studied, depending on the diagnostic characteristics. As the results are not based on expert knowledge, they need verification in the first sequence. It shall be remembered that the acquired public data are of subjective nature, but the convergence of many negative assess- ments of a given place clearly signals the low quality of space. Having already acquired such knowledge, it is worth looking at these areas and performing a kind of conditions study for them, i.e. to recognize the existing conditions. Depending on the factor under study, relevant "thematic layers" of data are taken into account for the analysis. An inventory of green areas and detailed greenery stock taking (trees and bushes) shall be used to analyze the quantity and quality of greenery, in line with other available data, including green management authorities. This paper presents an exemplary practical way of analyzing conditions in relation to selected issues. It consists in defining the built up by giving it a value adequate to the value of the space being marked up in value in which it is located. This makes easier the diagnosis of the existing condition, together with the design process itself. Figure 3 presents the rating of urban space in terms of quantity and quality of greenery against the background of general types and kinds of green areas (built-up areas in the neighbour-

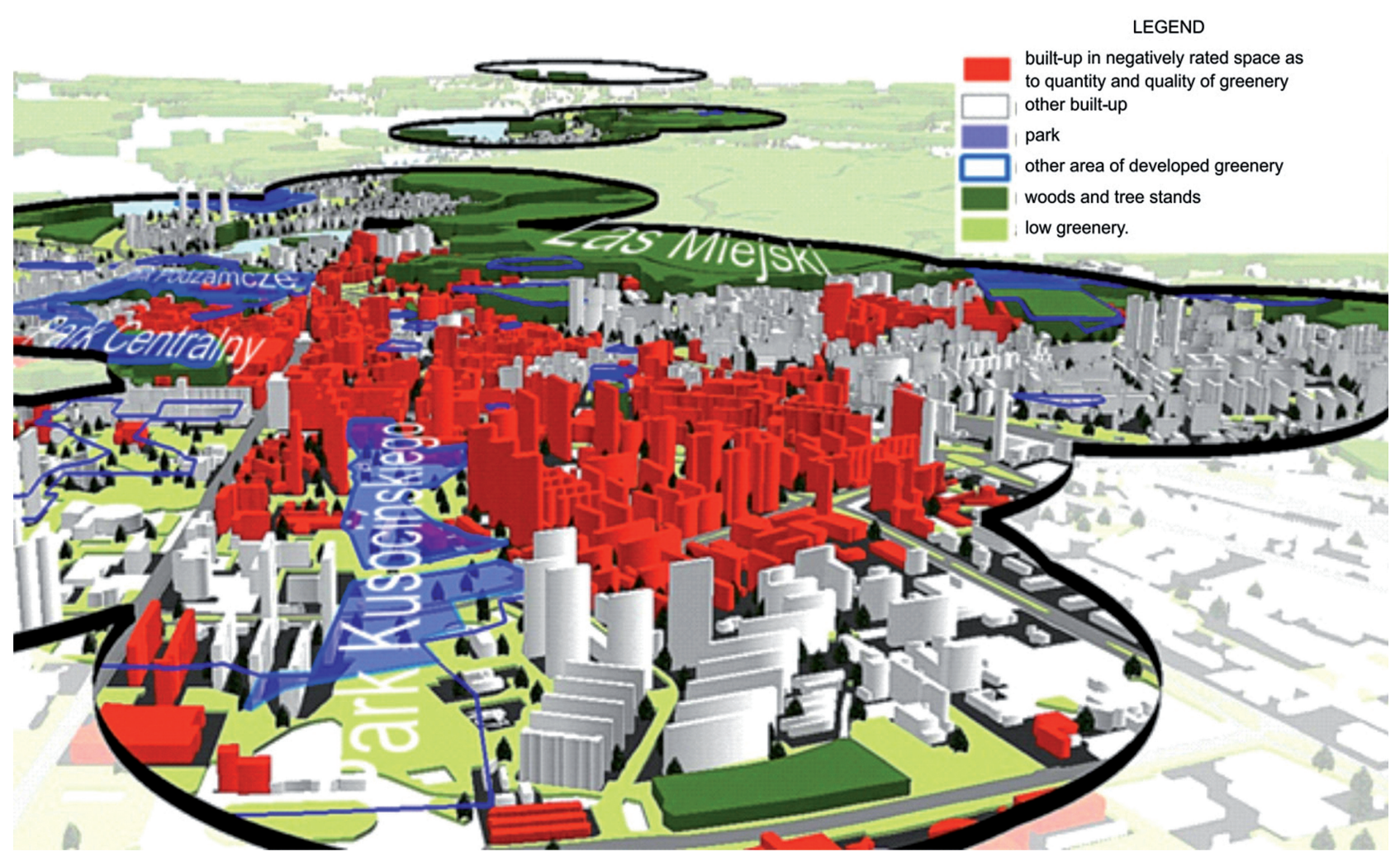

Fig. 3. Built-up in the space negatively rated as to the quality and quantity of greenery, at the background of selected green areas - view on Pojezierze Housing Estate

Rys. 3. Zabudowa w przestrzeni ocenionej negatywnie pod względem ilości i jakości zieleni, na tle wybranych terenów zieleni - widok na osiedle Pojezierze 
hood rated negatively by respondents are underlined. They can be the priority areas for greening over the city and improving the quality of greenery).

\section{ANALYSIS OF DETAILED SPATIAL DATA - RESPONDENTS' SUGGESTIONS OF CHANGES}

This stage of the research is based on the analysis of detailed spatial data (points) obtained in maps 3 and 4 of geosurvey and the identification of urban areas, specific sites, the most problematic ones included. The content of these cards relates to negative, unfriendly places, requiring changes. In the first case, the respondents were given the opportunity to indicate where, in their opinion, the greenery was in shortage. They also identified the type (or types) of the greenery in shortage and the type of green areas which the suggested vegetation is to refer to. Suggestions related to trees, bushes, annual and perennial plants, seasonal and temporary greenery (flower beds, structures and pots with flowers, etc.) and lawns. Respondents could refer to parks, green areas (squares, yards), housing estate green areas (accompanying buildings), recreation and sports grounds (playgrounds), street greenery (near traffic routes), and others not mentioned in the survey. The request to indicate the aforementioned sites made up an additional question in the case the signs on the map were not precise enough to be able to conclude on their specific attribution. This has also encouraged to indicate suggested surface green areas, such as parks or squares, which otherwise would need to be made more precise by drawing in the polygon shape.

The content of card 4 of the geosurvey concerns places requiring other changes and interventions than the introduction of green areas, i.e. where it is necessary to:

- introduce recreational amenities for children, playgrounds;

- provide sports and recreation amenities for youth and adults;

- introduce new amenities into small architectural elements (e.g. benches, seats, gazebos, rubbish bins, lighting, etc.);

- introduce or improve the condition of walking or cycling paths;

- improve the appearance of greenery, show greater care for greenery, tidy up the area;

- improve safety.
Respondents were also allowed to point out other needs for changes in the urban space, not mentioned in any of the above points. They were allowed to attach to each highlighted location a comment, giving details of a given problem.

Most observations (228) refer to places where, in the respondents' opinion, there is a greenery shortage. Other elements that require a special intervention are traffic infrastructure (in particular for pedestrians and cyclists) - 92 observations, green areas maintenance (85 observations) and providing for small architecture amenities (81 observations). By analyzing the share of suggestions for changes in individual housing estates in Olsztyn, one can conclude that housing estates that require a particular intervention in the urban space are: Kętrzyńskiego, City Centre and Jaroty Housing Estates. No remarks were reported as to Zielona Górka housing estate, and only one observation was noted in the Likusy and Redykajny housing estates, which related to recreational amenities for the young and adults, as well as shortage of greenery. Lack of greenery is most noticeable in Kętrzyńskiego estate (over half of all indications in this area). The greatest demand for providing the housing estate with elements of small architecture was demonstrated in City Centre and Jaroty housing estates. Most critical observations referring to improper solutions of traffic were recorded in Kętrzyńskiego Housing Estate. The City Centre and Jaroty HE are worst in terms of security. The greatest demand for children's recreational amenities (playgrounds) is in the City Centre and the Kormoran estate.

The above information signals the problems of most residents in urban space, and is the basis to develop directions and priorities for intervention. The greatest advantage of the acquired social data is their detailed spatial nature, owing to which exact sites for proposed changes can be analysed. Depending on the subject and scale of the design and development activities, the method of data analysis will be differentiated. In the case the actions are undertaken throughout the city, it seems of first importance to diagnose most problematic, and by the same prioritary areas within intervention actions in individual fields (the problem categories). High density of points (respondents' responses) indicates no public acceptance of the existing status and the need for change. If these demands address different issues at the same time, the given area is particularly problematic. 
To present quantitative spatial data in individual categories of proposed changes, a practical method was applied and the area of the city was divided into basic areas $-500 \mathrm{~m}$ squares. Trials to present results in the fields: both larger $(750 \mathrm{~m})$ and smaller $(250 \mathrm{~m})$ were made and it was found that the size of a $500 \mathrm{~m}$ square is most suitable, the number and spatial differentiation of data acquired taken into account along with the purpose and the scale of paper. Z. Kozieł $(1993,2003)$ turned attention to the fact that the scale of the map determines to a large extent the size of the basic field guaranteeing suitably detailed nature of studied phenomena and ensuring good legibility of map content. The presentation of results with the help of a net of squares is to allow for an easy identification of areas (regions) where changes in urban space are mostly desirable in the scale of the whole city. If the purpose of the paper were the identification of problematic areas within a part of the city, or its estates, it would be advisable to use the basic field of a smaller size, i.e. $250 \mathrm{~m}$ or to present the observation with the help of the dot method, where one point means one observation. Then, a greater spatial accuracy of data is desired.

Figure 4 presents the spatial layout of changes desirable in urban space of Olsztyn in the category of "elements of small architecture". The method of continuous cartogram was applied to present results.

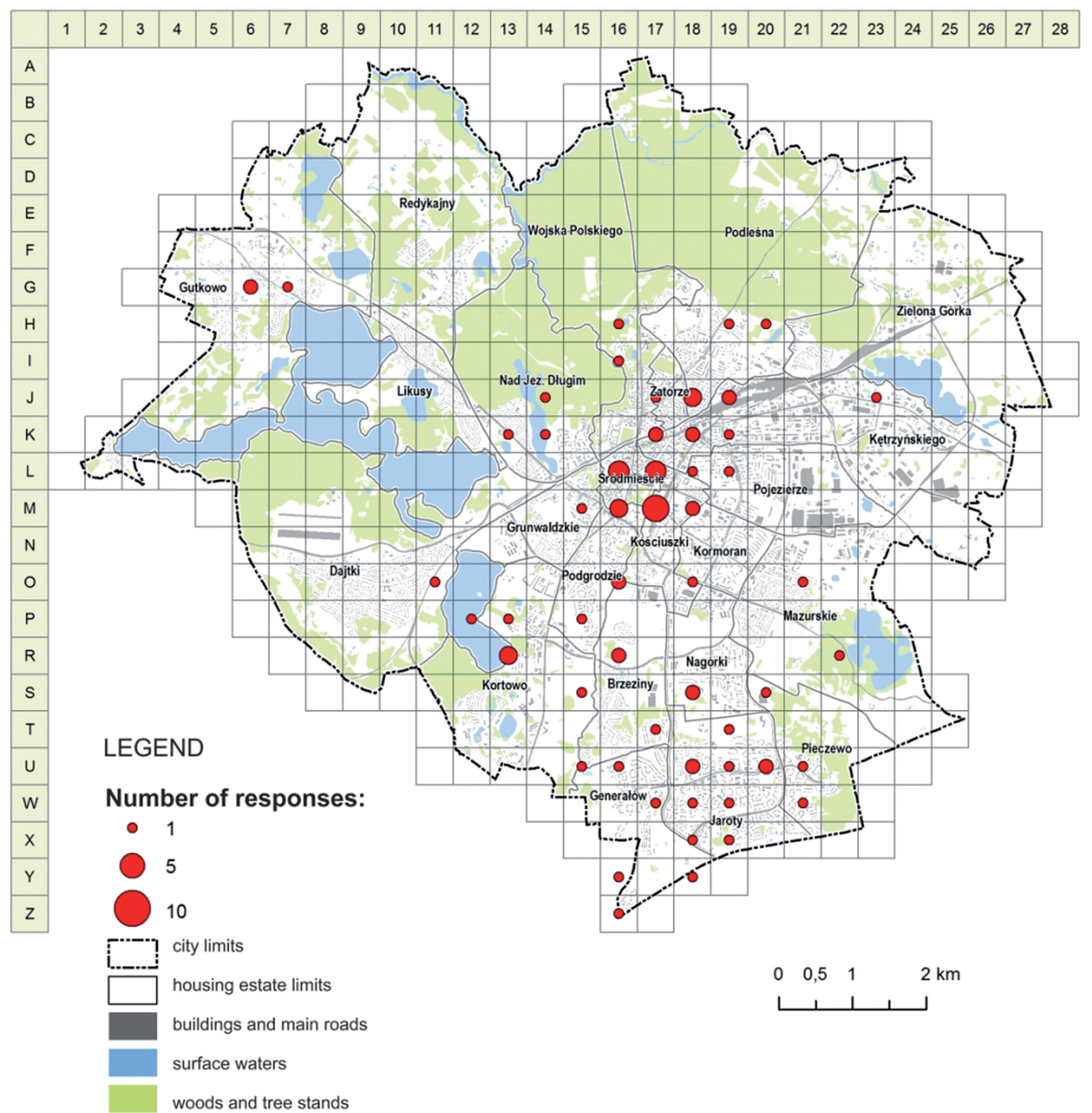

Fig. 4. Distribution of respondents' responses - changes in the category of SMALL ARCHITECTURE ELEMENTS Rys. 4. Rozmieszczenie liczby wskazań respondentów - propozycji zmian w kategorii ELEMENTY MAŁEJ ARCHITEKTURY 
The greatest demand for elements of small architecture (the greatest density of responses) occurs in the City Centre;

- Near the Central Park and Emilii Plater Street, Kościuszki Street and Żołnierskiej Street (17M) -6 responses

- Near the Old Town and the City Hall as well as 1 Maja Street (16L) - 17 responses

- In the area between 1 Maja Street and Kościuszki Street $(17 \mathrm{~L})-24$ responses.
In order to identify the most problematic areas of the city needing intervention, all fields of activity taken into account, the responses from the individual categories discussed above are summarized. The results are shown with the help of a cartogram (Figure 5).

Areas with the highest number of responses (proposals for changes in urban space) are concentrated in the central part of the city (the City Centre/Śródmieście housing estate, the western part of the Kętrzyńskiego estate, the northern part of the Kościuszko housing es-

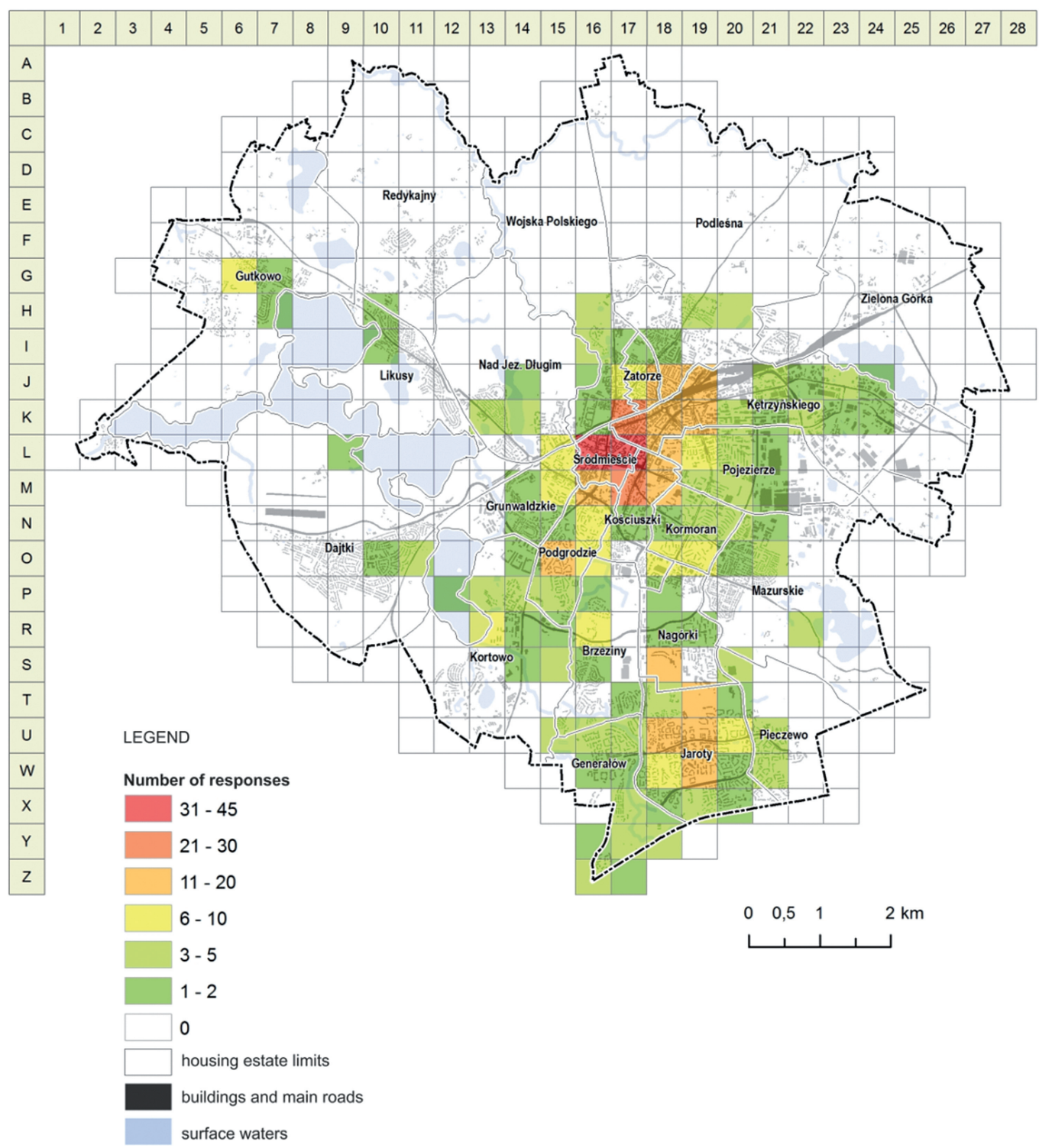

Fig. 5. General distribution of respondents' responses (suggestions of changes) altogether in all categories

Rys. 5. Ogólne rozmieszczenie liczby wskazań respondentów (propozycji zmian) łącznie we wszystkich kategoriach 


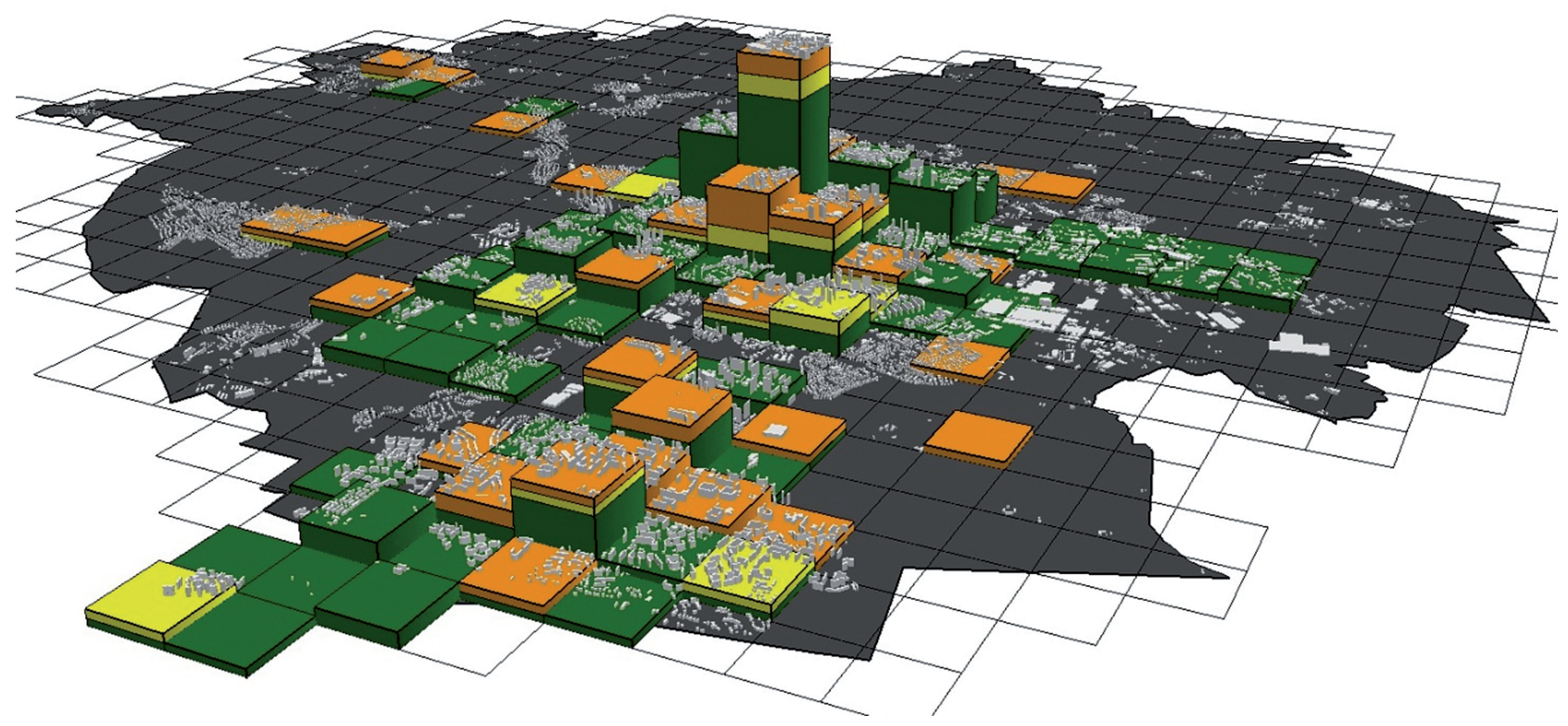

Fig. 6. Distribution of respondents' responses in three from eight categories of suggestions of changes

Rys. 6. Rozmieszczenie liczby wskazań w trzech, spośród ośmiu kategorii propozycji zmian

tate, the northern and central part of the Podgrodzie estate) and in the southern part of the city, most of Jarota housing estate and the south part of Nagórki estate. However, the most prioritory areas of intervention within the city are:

- area between 1 Maja Street and Kościuszko Street (17L) - 45 responses;

- Old Town and surroundings of the City Hall and 1 Maja Street (16L) - 33 responses;

- part of the city between Wojska Polskiego Avenue in the west to the junction of Dabrowszczaków Street and Partyzantów Street in the east and the crossing of Wojska Polskiego Avenue and Jagiellońska Street in the north to Konsulatu Polskiego Square in the south $(17 \mathrm{~K})-27$ responses.

To make practical analyzes of social data in relation to the existing land use the block diagram method has been suggested. Owing to it, both the distribution and size of the phenomena related to the necessary changes in urban space can be presented. The results can be interpreted practically by compiling layers of all 8 categories, which previously were analyzed independently. Figure 6 shows three of them: no greenery (green layer), no playgrounds (light yellow layer), no sports and recreational sites for youth and adults (orange layer). Depending on the needs (analyzed issue), appropriate layers can be selected for analysis, both social data and those relating to existing or planned land development, e.g. buildings, parks, other green areas, playgrounds etc.

The above analyzes show the spatial distribution of observations based on their aggregation in a grid of geometric fields. However, it shall be remembered, that although in this way locations numerical distribution can be identified clearly along with most problematic city areas, but the locations of an increased occurrence of a given phenomenon, cannot be identified. It is the clusters of the individual phenomena studied which are most important in the design process within the priority actions. One can assume that the higher density of points (respondents' responses), the less public acceptance for the condition of a given urban space. The Kernel density estimation method was used to identify the specific sites (locations) to which residents have most objections and negative feedback. The kernel density function calculates the density of points (observations) in the neighbourhood of these points (B. Silverman 1986).

The cluster analysis was performed both for total observations and for those in particular categories of phenomena (in tables). An example of an analysis related to places where the lack of greenery is most noticeable in the city is presented in Table 1, together with Figure 7. 


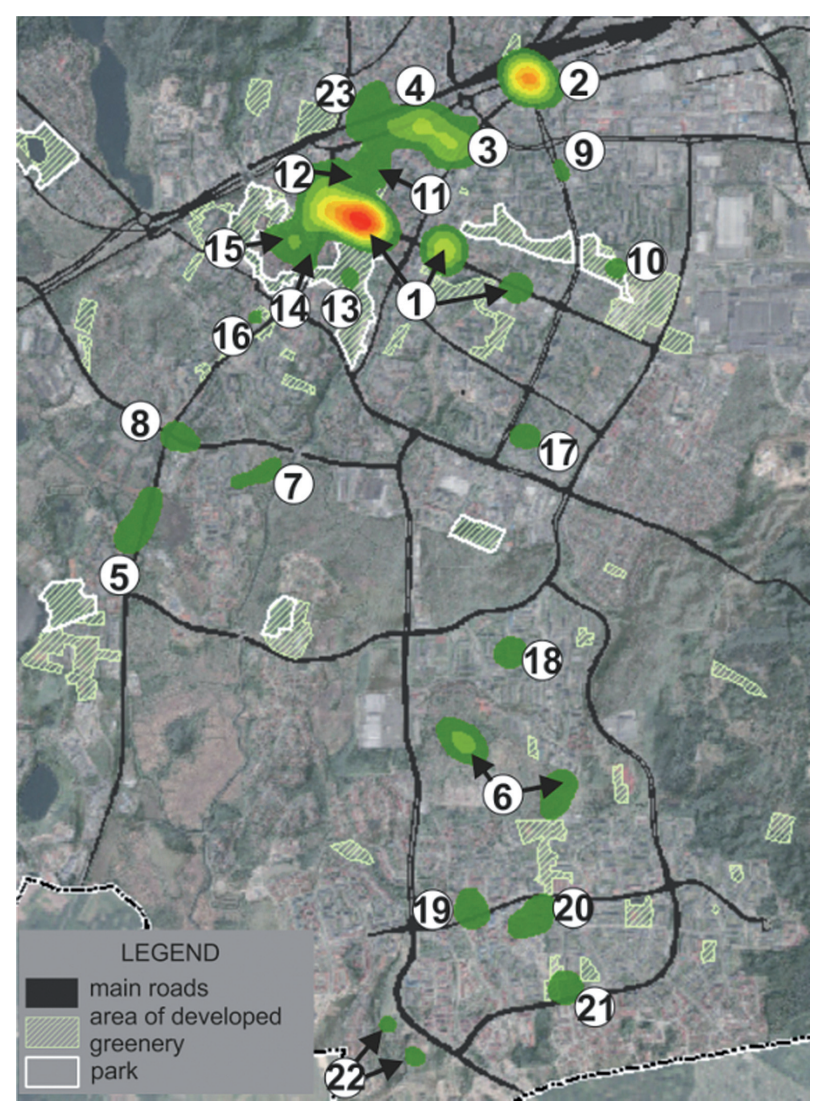

Fig. 7. Analysis of no greenery clusters (on the orthophotomap from geoportal: http://geoportal.gov.pl/)

Rys. 7. Analiza skupień wskazań dotyczących braku zieleni (na podkładzie ortofotomapy pochodzącej z geoportalu: http://geoportal.gov.pl/)

\section{IDENTIFICATION AND DEVELOPMENT OF POSITIVE, FRIENDLY AND IMPORTANT PLACES IN THE CITY OR HOUSING ESTATE}

This stage of the study process is based both on the analysis of detailed spatial data (points) obtained in maps 1 and 2 of geosurvey and identification of city areas, including given sites, most valuable and important in the city or housing estate scale. The content of these cards refers to positive, friendly and important locations. In the first of them, respondents were given the opportunity to indicate their favourite places of leisure time. They also defined, among other things, the type of activities performed and the main factor that determines the choice of a given place to do them. The content of card No. 2 refers to other valuable and important plac- es, or else those which they do not frequent, but which have or could have significant importance for the city or the housing estate.

Subjects of both card 1 and card 2 were rated by the respondents with regard to the following 5 factors: importance for spatial order, natural values, historical and cultural values, public values (leisure and recreation), entertainment values. These factors were rated in a 6-step scale ("I do not think", "very small", "small", "medium", "big", "very large").

The factors that received a total of at least 5 responses in the said two categories were to be increased in value by the method of point bonitation. Each facility was to receive not more than 5 points (for highest rating) and a minimum of 1 point (for the lowest rating). In the case, the respondent chose the "I have no opinion" reply, their vote was not taken into account at all.

Figure 8 shows the 21 sites most frequently referred to as recreation sites or as valuable and important places. Among the places with the highest number of responses were: Central Park, the area around Lake Długie, Podzamcze Park, Municipal Forest, "Ukiel”, Recreation and Sports Centre.

The assessment of sites with regard to adopted factors consisted in finding the mean of respondents' assessments, independently for each factor. The results of point bonitation have been presented in five maps, one of examples (for a selected factor) is Figure 9.

The mean values of the points from the individual partial increase in value were summed up and the general development of the sites was carried out. The most valuable and significant sites, according to the respondents, are: Stadion Leśny/Forest Stadium - 20.96 pts, Podzamcze Park - 20.21 pts, Municipal Forest - 20.01 pts, area around Lake Dlugie - 19.98 pts, "Ukiel" Recreation and Sports Centre - 19,14 points, Central Park18,60 points, Jakubowo Park - 18,54 points.

While analyzing the relationships between the perception and assessment of sites by the respondents and their suggested changes, the following conclusions can be drawn:

1) Lack of responses related to suggestions for changes in space need not be equivalent with the public acceptance. An example is Lasek Pieczewski (site No. 14), for which no suggestions for changes were given, but in the overall assessment, it received a low score. The property is quite often frequented by the residents of the sur- 


\begin{tabular}{|c|c|c|c|}
\hline \begin{tabular}{|c|} 
Item acc. \\
to fig. 9
\end{tabular} & Location & Type of greenery & Suggested (types of) greenery \\
\hline 1 & $\begin{array}{l}\text { Piłsudskiego Av. (in particulars near the } \\
\text { City Hall and the Aura Mall as well as from } \\
\text { Kościuszki Street to Dworcowa Street } \\
\text { Solidarności Square } \\
\text { Jana Pawła II Square } \\
\text { Xawerego Dunikowskiego Square }\end{array}$ & $\begin{array}{l}\text { Street greenery } \\
\text { square } \\
\text { square } \\
\text { square }\end{array}$ & $\begin{array}{l}\text { All types given in the questionnaire to } \\
\text { the same degree, with trees prevailing } \\
\text { All types given in the questionnaire }\end{array}$ \\
\hline 2 & $\begin{array}{l}\text { Konstytucji } 3 \text { Maja Square } \\
\text { / Lubelska Street (Near the Central Rail- } \\
\text { way Station) }\end{array}$ & $\begin{array}{l}\text { Street greenery } \\
\text { /greenery accompanying } \\
\text { the built-up / the greens }\end{array}$ & $\begin{array}{l}\text { All types given in the questionnaire, } \\
\text { with trees and bushes prevailing }\end{array}$ \\
\hline 3 & $\begin{array}{l}\text { Pułaskiego Square and surrounding resi- } \\
\text { dential built-up }\end{array}$ & Square/HE greenery & $\begin{array}{l}\text { Bushes, one year and perennial plants } \\
\text { beds, seasonal greenery }\end{array}$ \\
\hline 4 & Partyzantów Av. & Street greenery & $\begin{array}{l}\text { All types given in the questionnaire, } \\
\text { with trees prevailing along with sea- } \\
\text { sonal greenery and lawns }\end{array}$ \\
\hline 5 & $\begin{array}{l}\text { Warszawska Av. and. Heweliusza St. (for- } \\
\text { mer bus terminal) }\end{array}$ & $\begin{array}{l}\text { Street greenery } \\
\text { / square }\end{array}$ & Trees and bushes \\
\hline 6 & $\begin{array}{l}\text { Area of undeveloped greenery between } \\
\text { HEs of Nagórki and Jaroty }\end{array}$ & Park & $\begin{array}{l}\text { All types given in the questionnaire, } \\
\text { with trees and bushes prevailing along } \\
\text { with one year and perennial plants beds }\end{array}$ \\
\hline
\end{tabular}

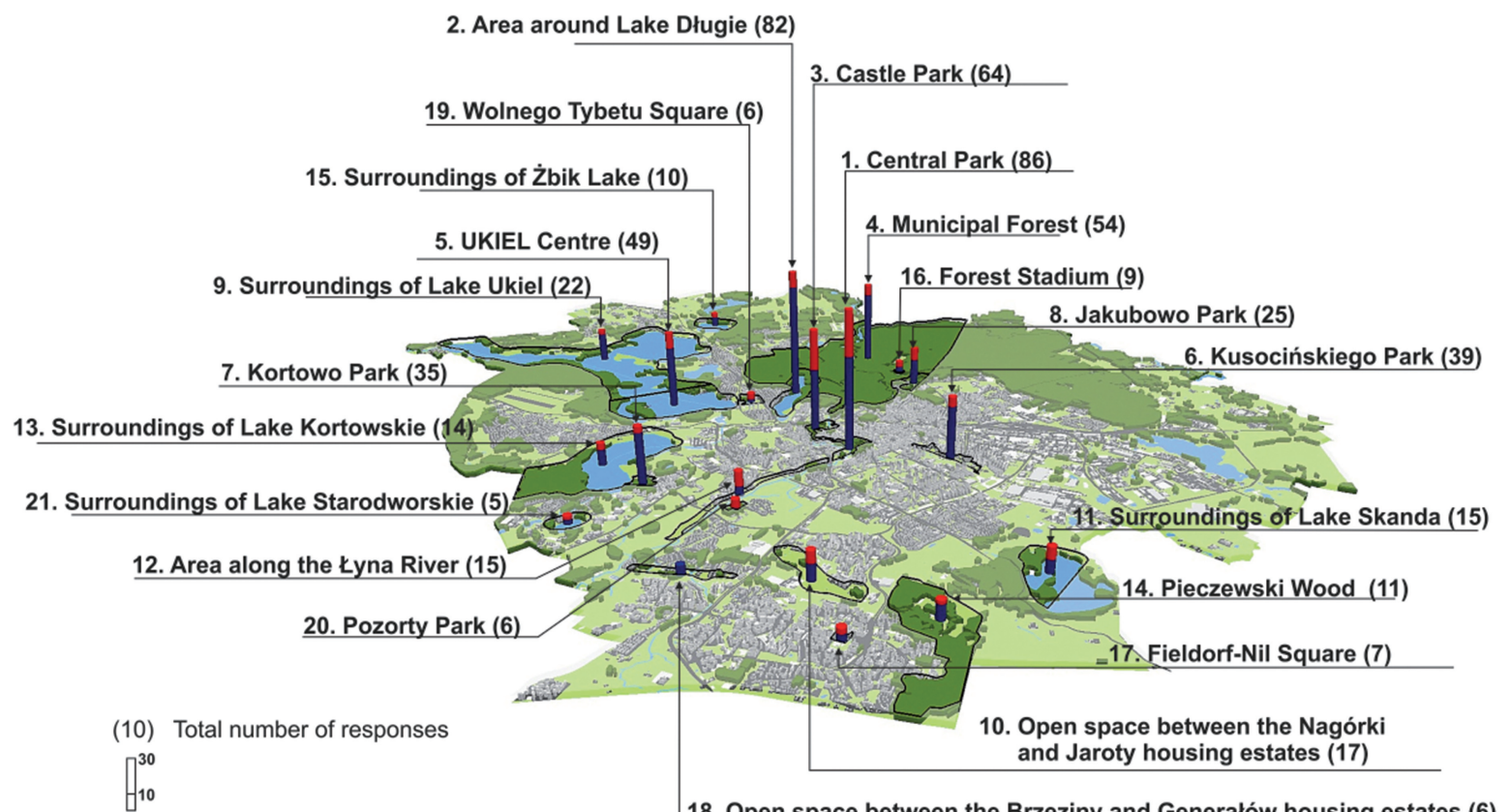

Responses choosing the site for leisure

Responses choosing valuable and important sites

Fig. 8. Sites most frequently indicated by the respondents as sites of recreation or as valuable and important places Rys. 8. Obiekty najczęściej wskazywane przez respondentów jako miejsca rekreacji lub jako miejsca ważne i wartościowe 


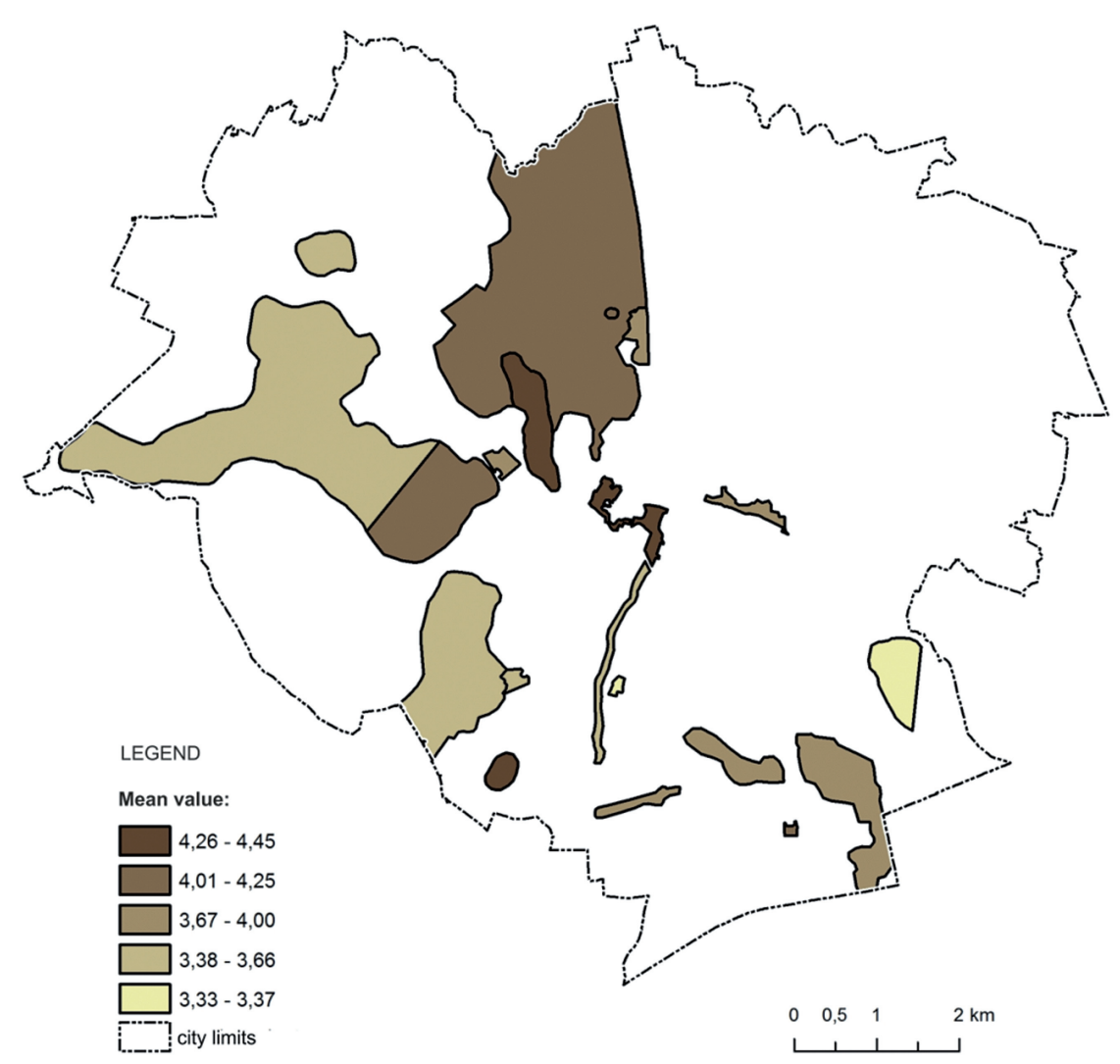

Fig. 9. Rating with regard to IMPORTANCE FOR SPATIAL ORDER

Rys. 9. Ocena obiektów pod względem ZNACZENIA DLA ŁADU PRZESTRZENNEGO

rounding housing estates. It has been also designated twice as a key site in the housing estate. Residents recognize the high natural values of this place and its importance for spatial order, but notice rather low social values, i.e. leisure and recreation offer. Thus, putting into life of the fourth stage of the study, i.e. the identification of valuable sites, also allows to identify their weaknesses, which is particularly valuable if the results of previous analyzes have not shown them.

2) Residents recognize the potential of sites that currently is not fully (or not at all) used. An example is the Forest Stadium, which scored the largest number of points in the overall assessment. Other sites to be noted are the area along the Łyna River (including the section of the planned Łynostrada cyclists' path), Pozorty Park and the undeveloped green area between the Nagórki and Jaroty housing estates. There were suggestions for changes and improvements in these three areas. These sites were more frequently considered important and valuable than convenient places of leisure. In the case of an inter-housing estates, unarranged greenery, the responses choosing this site prevail as a recreation area because of its proximity to the places of residence.

3) sites considered to be most valuable and important in urban space (high scoring in general opinions) do not need to enjoy total public approval. Park Podzamcze and Central Park are examples, in relation to which (in particular in relation to the latter one) the residents pointed out suggestions for changes and even ready solutions. This means that even though these sites are one of the most frequently visited places in the city, they require some action that could improve the quality of space and make them even more hospitable to the local residents. 
To sum up, it can be stated that the proposed fourth stage of the study process, consisting in the identification of valuable sites, is a very important stage, complementing the analysis presented in the earlier part of the paper. It could seem proper to leave to experts the assessment of sites in urban space with regard to various factors. However, it is worthwhile, in the designing and revitalization process, to perform additionally a public survey of space, which together with expert assessment can be used to draw up urban green space development programmes. This gives the opportunity to become familiar with the actual functions of the sites and their significance to the residents. This draws attention to the sites, their strengths which need to be exposed and protected included, and also to the weaknesses of spaces which in turn require intervention.

Regardless of the implementation of the social development of sites, it is also worth of attention to focus on their own social values, i.e. the leisure and recreation offer. The most popular sites (as shown in Figure 8 ) include the area around Lake Długie (72 responses), Central Park (58 responses), the Municipal Forest (47 responses), Ukiel Recreation and Sports Centre (39 responses), Park Podzamcze (39 responses), Kusociński Park (33 responses) and Kortowo Park (31 responses).

However, it is good to keep in mind the fact that not always a high frequency of use of a given site proves its rich leisure and recreation offer. Sometimes it is only the proximity from the place of residence, work or school that determines the choice of a site for recreation. Such information was also obtained in the study.

Based on the data obtained from card No. 1 of geosurvey, it is possible to analyze such issues as: frequency of given sites visiting, types of activities carried out, main determinants for choosing a site to spend free time there. The information on the respondents' addresses allows to determine the directions from which the residents move to different sites of recreation and to identify the range of the sites influence.

The acquired social data allow to carry out a similar characteristics for all sites in the city, in particular those most frequented. They allow to identify actual functions, importance and programmes of individual sites. Besides the information on the needs and preferences of the users, these data make up a basis to draw up designing guidelines and recommendations, for instance for the needs of green space development programmes.
The surveys carried out in different periods of time can help to set out the dynamics of site development and compare more important trends in different times so as to adjust the programme to actual demand (A. Zachariasz 2006).

The authoress identified only selected, mostly frequented recreation sites in the city in consequence of the scale of the survey conducted (the whole city). However, conducting a more detailed survey (for instance within a given housing estate) with the help of cluster analysis, less frequently visited sites should be identified (clusters with smaller density of points), and amongst large-space sites (for instance the surroundings of Lake Ukiel) the zones whose frequency of visiting is largest had better be separated and analysed.

\section{AN ATTEMPT TO FORMULATE DESIGN GUIDELINES}

On the basis of the results of all stages of the research process, general design guidelines (city-wise) have been formulated which cover, among other things, the following:

- improving the cycling and pedestrian amenities (especially in Partyzantów Street, Kościuszki Street, Piłsudskiego Av.);

- improving the care for greenery, particularly in Kętrzyńskiego, Śródmieście and Jaroty housing estates;

- improving the care for new compensatory planting;

- improving the care of green areas, introducing new amenities (small architecture), particularly benches and seats, and waste baskets (especially in Śródmieście and Jaroty housing estates);

- increasing the number but also diversity of plantings, introducing interesting plant compositions, for instance ornamental grasses;

- improving the accessibility of green areas for disabled people and baby push chairs;

- catwalks;

- better use of the potential of lakes in the city, e.g. Lake Kortowskie and Lake Skanda and the Łyna River (in the section from Kalinowskiego Street to Niepodległości Avenue).

Based on the results obtained, it was also possible to develop detailed guidelines for particular sites of urban space, in form of the so-called area cards. These cards 
contain assumptions how to shape spatially the sites, which along with the assumptions drawn up by experts can make up a part of green space development programmes or their management plans.

\section{SUMMARY AND CONCLUSIONS}

The application of the softGIS method (geosurvey) in the research allowed to obtain from residents in a simple and quick way many valuable spatial and non-spatial data - of complementary nature which can be used at every stage of action related to the spatial creation (from research and pre-design analyses to the stage of maintenance and operation of sites). By fulfilling the objective of the research, a number of interesting both quantitative and qualitative data on the urban space of Olsztyn were obtained. The type and nature of the data acquired could be different to a large extent. The paper presents selected possibilities of using the Internet public participation in the process of urban green areas designing and revitalizing, based on an example of the author's geosurvey. The content of the geosurvey questionnaire has been developed so that the answers to the questions contained therein would allow to make analyzes shown in the five stages of the research process.

The first stage was to find the respondents' general opinion and rating of green areas. It reveals the general rating and opinions of space users on the manner of developing individual green areas in the city and suggested changes in the direction, shaping and management of urban greenery. The results acquired are to draw attention to areas of action which in the opinion of residents do not function well enough and need to be improved. The implementation of this stage may also supplement cyclical opinion polls and help to formulate general guidelines and directions for green areas development in the city.

Residents' knowledge on the neighbourhood of the place of residence was used to assess the quality of urban space for the second stage of study, based on spatial qualitative data. The aim is to become familiar with the level of public acceptance of space with regard to various factors, affecting its quality and attractiveness. The research con contribute to a preliminary diagnosis of problem areas as to various criteria, depending on the diagnostic characteristics adopted. It can be reached as an introduction to further analyses of the quality of space.
The third stage makes up an analysis of detailed spatial data in the form of respondents' responses related to suggestions for changes in urban space. It shows particular needs of the residents, often in the form of readymade design solutions. It can be used:

- as a complement to two previous stages:

- for the development of urban design and revitalization directions (eg for green spaces planning programmes, planning documents such as land use planning and spatial layout plans);

- for housing estates planning purposes (for example, for applications to use Citizens' Budget);

- regardless of the previous stages - in the framework of diagnosing local needs of residents (small land development projects, i.e. compensatory planting, planning for sports and recreation sites, etc.).

The analysis of sites of particular importance and value for the residents also helps to come to conclusions crucial for the designing purpose, besides the analysis of negative places and those requiring changes. This analysis represents the suggested fourth stage of study. It allows to identify the sites of leisure for the residents, as well as other important places that can be of importance to the city or housing estate. This stage can be implemented for the needs of programmes and strategies for shaping municipal green areas or local revitalization programmes, where the most valuable and significant sites need to have different guidelines with regard to their maintenance and use so as to maintain and protect these facilities in a particular manner.

The summary of the research process was an attempt to formulate general design guidelines (recommendations) for the entire city and detailed guidelines for two selected urban green spaces in form of site cards as master cards. The guidelines developed based on the knowledge of residents compared with the expert guidelines assure a full picture of the strengths and weaknesses of the green space of the city.

The stages of research that lead to drawing up the guidelines can be implemented independently, as needed. The results of analyses, however, have shown that these studies complement each other. Presented potential to acquire data with the use of geosurvey questionnaire and later analyses and their use present great possibilities of this type of tool in landscape architecture, 
in the process of designing and revitalizing urban green spaces. With the increased popularity of the Internet and geographic information systems, geosurvey could be a perfect supplement to the practised forms of public consultation.

\section{BIBLIOGRAPHY}

Hasanzadeh K., 2014, SoftGIS Data Mining and Analysis: A Case Study of Urban Impression in Helsinki (Master's Thesis), https://aaltodoc.aalto.fi/bitstream/handle/123456789/13123/ master_Hasanzadeh_Kamyar_2014.pdf?sequence $=1$ [dostęp: 15.05.2015].
Kozieł Z., 1993, Barwny kartogram złożony jako metoda badań i prezentacji wybranych zjawisk geograficznych. Torun: Wydawnictwo UMK, 30-33.

Kozieł Z., 2003, Geokompozycyjno-wizualizacyjne aspekty modelowania rzeźby terenu wobec współczesnych procedur pozyskiwania i przetwarzania danych, Torun: Rozprawy habilitacyjne UMK.

Silverman B. W., 1986, Density Estimation for Statistics and Data Analysis. New York: Chapman and Hall.

Skiba M., 2008, Rozmyte miary percepcji krajobrazu, w: U. Myga-Piątek, K. Pawłowska (red.), Zarządzanie krajobrazem kulturowym, Sosnowiec: Komisja Krajobrazu Kulturowego PTG, 123-130.

Zachariasz A., 2006, Zieleń jako współczesny czynnik miastotwórczy ze szczególnym uwzględnieniem roli parków publicznych, Kraków: Wydawnictwo Politechniki Krakowskiej. 